\title{
RISK ANALYSIS OF ISLAMIC BANKING FINANCING BUSINESS IN INDONESIA 2014-2018
}

\author{
Herlan Firmansyah \\ Faculty of Economic and Business of Islam Universitas Suryakancana Cianjur, \\ J1. Pasirgede Raya, Bojongherang, Cianjur, Bojongherang, Kec. Cianjur, \\ Kabupaten Cianjur, Jawa Barat, Indonesia, 43216 \\ Email: herlan@unsur.ac.id \\ Mohamad Anton Athoillah \\ Faculty of Sharia and Law, Universitas Islam Negeri Sunan Gunung Djati \\ Bandung, J1. A.H. Nasution No.105, Cipadung, Kec. Cibiru, Kota Bandung, \\ Jawa Barat, Indonesia, 40614 \\ Email: anton_athoillah@uinsgd.ac.id
}

\begin{abstract}
The purpose of this article is to analyze business risk in Islamic banking financing in Indonesia. The method used in this study is a qualitative research method with a descriptive approach. The data used in this study are secondary data sourced from Sharia Banking Statistics (SBS). The conclusions of this article are ten business risks that must be managed by Islamic banks in carrying out their functions, namely financing risk, market risk, liquidity risk, operational risk, legal risk, reputation risk, strategic risk, compliance risk, yield risk, yield risk, and investment risk. Four business risks affect the profitability of Sharia Commercial Banks (BUS) in Indonesia, namely financing risk as measured by NPF, the rupiah exchange rate measures market risk against the USD and inflation, return NCD measures risk on total deposits and investment risk measured by the percentage potential loss profit-sharing financing for mudharabah and musyarakah investment portfolios.
\end{abstract}

Keywords: Business Risk; Financingl; Profitability; Islamic Banking

How to Cite: Firmansyah, H., \& Athoillah, M. A. (2019). Risk Analysis of Islamic Banking Financing Business in Indonesia 2014-2018. Jurnal Ilmiah Al-Syir'ah, 17(2), 131-149.

Permalink/DOI: http://dx.doi.org/10.30984/jis.v17i2. 957

Copyright (C) 2019, Jurnal Ilmiah Al-Syir'ah 


\section{INTRODUCTION}

Islamic banks, as business entities, have the purpose of gaining profits. The advantages of Islamic banks derived from their main activities, namely financing. According to Al Arif, financing is funding provided by a party to other parties to support planned investments, both by themselves and institutions (Arif, 2012).

Veithzal Rivai and Andria Permata Veithzal concluded that in practice financing was realized in the form of; (1) Submission of present economic value to trust in hopes of regaining a similar economic value in the future; (2) An action on the basis of an agreement in the agreement includes services and remuneration (achievements and counter-achievements), both of which are separating by time; (3) Financing is a right, with the right to which one can use it for specific purposes, within a specified time limit and at certain considerations (Rivai \& Veithzal, 2008).

The Law Number 21 of 2008 concerning Sharia Banking article 1 explains that financing is the provision of funds or bills that are equaling in the form of; (1) Profit sharing transactions in the form of mudharabah and musyarakah; (2) lease transactions in the form of ijarah or lease purchase in the form of ijarah muntahiya bittamlik; (3) Sale and purchase transactions in the form of murabahah, salam, and istishna receivables'; (4) Lending and borrowing transactions in the form of qardh receivables; and (5) service lease transactions in the form of ijarah for multi-purpose transactions.

Financing channeled by Islamic banks is expected to provide sustainable and ethical quality income. The quality of financing that is not good or even deteriorates will have a direct impact on the decline in income and profits obtained by Islamic banks (I. B. Indonesia, 2015b). Thus, the level of ability of Islamic banks to generate profits from their business activities or commonly called profitability, one of which will depend on the quality of the financing channeled.

Profitability is a measure of a company's ability to generate profits from the normal activities of its business (Hery, 2015). Profitability will be high when Islamic banks can maintain the quality of the financing they distribute. The quality of financing is determining the performance of risk management by Islamic banks. Risk in the context of Islamic banking is a potential event, both predictable and unpredictable, which hurts bank income and capital (Indonesia, 2015).

Based on Islamic Banking Statistics (SPS) published by the Financial Services Authority (OJK), particularly regarding the business performance of Sharia Commercial Banks (BUS) and Sharia Business Units (UUS) in Indonesia it is known that there are phenomena of Islamic banking profitability fluctuations in the 2017 and 2018 periods. The value of Return on Assets (ROA) of BUS and UUS in 2017 and 2018. BUS of ROA in December 2017 was $0.63 \%$, decreased at the beginning of 2018,i.e., January 2018 to be $0.42 \%$, and in the month December 2018 rose to $1.28 \%$. The ROA 
of UUS in December 2017 was 2.47\%, a decline in December 2018 to become $2.24 \%$.

Table 1. Development of Financial Ratios Sharia Commercial Bank (BUS) and Sharia Business Units (UUS) in Indonesia 2014-2018 Period

\begin{tabular}{|c|c|c|c|c|c|}
\hline \multirow{2}{*}{ No } & \multirow{2}{*}{ Year } & \multicolumn{2}{|c|}{ BUS } & \multicolumn{2}{|c|}{ UUS } \\
\hline & & NPF & ROA & NPF & ROA \\
\hline 1 & 2014 & $4,95 \%$ & $0,42 \%$ & $2,55 \%$ & $1,97 \%$ \\
\hline 2 & 2015 & $4,84 \%$ & $0,49 \%$ & $3,03 \%$ & $1,81 \%$ \\
\hline 3 & 2016 & $4,42 \%$ & $0,63 \%$ & $3,49 \%$ & $1,77 \%$ \\
\hline 4 & 2017 & $4,76 \%$ & $0,63 \%$ & $2,11 \%$ & $2,47 \%$ \\
\hline 5 & 2018 & $3,26 \%$ & $1,28 \%$ & $2,15 \%$ & $2,24 \%$ \\
\hline
\end{tabular}

Source: Islamic Banking Statistics, Financial Services Authority (OJK) (www.ojk.go.id Accessed February 20, 2019)

Based on table 1.1 above, it appears that the financial ratios of Islamic banking, especially BUS and UUS in Indonesia for the 2014-2018 period, especially NPF and ROA, have fluctuated. Besides being due to macroeconomic slowdown factors, the still weak fund management and risk management carried out by Islamic banking are thought to be part of the trigger for this phenomenon to occur.

According to the Indonesian Bankers Association, funding is one of the bank's leading businesses. Therefore, financing is the primary source of income for Islamic banks; financing must manage in such a way as to provide high profits for Islamic banks. Funding channeled by Islamic banks is expected to contribute to sustainable income, and always be in good quality for some time. The effectiveness of financing, which has a direct impact on sharia banking business productivity, is one of the factors influenced by the effectiveness of risk management carried out by sharia bank managers (Indonesia, 2015).

Risk is a potential loss due to the occurrence of certain events (B. Indonesia, 2011). Fachmi Basyaib argues that risk is defined as the opportunity for the occurrence of undesirable results so that risks are only related to situations that allow negative results to emerge and are related to the ability to predict the occurrence of negative results. While risk management is a series of methodologies and procedures used to identify, measure, monitor, and control risks arising from all Bank business activities (B. Indonesia, 2011).

The fluctuations in the profitability of Islamic banking in Indonesia indicate that business risk mitigation has not been optimal; this certainly has an impact on the level of public confidence in partnering with Islamic banking. Furthermore, it has an impact on the slowing growth of the market share of Islamic banking. Based on OJK data, it knows that until the end of 2018, the market share of Islamic banking in Indonesia has only reached $5.7 \%$. 
Based on the description above, the authors are interested in conducting a more in-depth study of risk analysis of Islamic banking business in Indonesia, especially after the transition phase of the banking industry regulation and supervision function from Bank Indonesia (BI) to the Financial Services Authority (OJK), 2014-2018.

Research related to business risk analysis conducted by several researchers, including Sidiq who concluded that Islamic banking has a significant activity, namely channeling and collecting funds from the public (Sidiq, 2018). Funding to customers aims as income to increase profitability. However, on the other hand, the Islamic bank needs to pay attention to all the risks that continue to accompany the distribution of funds such as credit risk and liquidity risk. Then Ansori and Safira, concluded that in general, risk management of Conventional Commercial Banks and Sharia Commercial Banks in this study had an influence on profitability, the difference was only in the LDR variable, where the conventional commercial banks did not affect as well as research conducted by Shafira which concluded that the comparison of financial risks in conventional and sharia banks in 2012-2017 showed that there were significant differences in credit risk, liquidity risk, and operational risk. While there is no significant difference in market risk between conventional banks and Islamic banks, from the three previous studies, this study will analyze business risks in Islamic banking financing in Indonesia with indicators of financing risk, market risk, liquidity risk, operational risk, legal risk, reputation risk, strategic risk, compliance risk, yield risk, and investment risk (Ansori \& Safira, n.d.).

\section{RESEARCH METHODS}

The method in this research is descriptive. Descriptive methods, namely research methods that emphasize the effort to obtain information about the status or symptoms at the time of research, provide an overview of phenomena, also further explain the relationship, and attract the meaning of the desired problem. Descriptive research is a form of research that is the most basic and is intended to describe or describe existing phenomena, both phenomena that are natural or human engineering. Nyoman Dantes explains that descriptive research defined as research that attempts to describe a phenomenon or event systematically according to what it is. In this case, the researcher tries to determine the nature of the situation as it was at the time the research was conducted (Dantes, 2012).

The descriptive method also interpreted as a method in the research of the status of human groups, objects, conditions, a system of thought, or a class of events in the present. Descriptive research aims to make a description, description, or painting systematically, factually, and accurately of the facts, characteristics, and relationships between the phenomena investigated (Saebani \& Abdullah, 2014).

The type of data used is secondary data. Suryani da Hendryadi explained that secondary data is data obtained incomplete forms, already collected and processed by other parties, usually in the form of publications (Suryani \& Hendryadi, 2015). Singgih Santoso and Fandy Tjiptono as quoted 
by Muhammad explained that there are several advantages of secondary data, namely saving time and costs, relatively more accessible, useful to help identify problems, useful in supporting the formulation of research problems more accurately, helping to form research designs the right, helps in drafting or approaching the problem, helps identify the need for more in-depth research, answers specific research questions and tests several hypotheses, and provides comparative data so that primary data can be identified more accurately (Muhammad, 2000).

Secondary data used are secondary data sourced from Islamic Banking Statistics (SPS) in Indonesia, which are officially published by Bank Indonesia and the official website of the OJK as the authorized authority to regulate, supervise and protect Islamic banking in Indonesia.

The object of study in this paper is Islamic banking in the form of BUS. The UUS and BPRS do not use as objects of study about the economies of scale and operational activities of UUS and BPRS, which are relatively more limited compared to BUS. The list of BUS as stated in Islamic Banking Statistics (SPS) published by OJK, is as follows.

Table 2. Sharia Commercial Bank (BUS) in Indonesia Period of December 31, 2018

\begin{tabular}{clcl}
\hline No & \multicolumn{1}{c}{ Name of Bank } & No & \multicolumn{1}{c}{ Name of Bank } \\
\hline 1 & PT. Bank Muamalat Indonesia & 8 & PT. Bank Panin Syariah \\
2 & PT. Bank Victoria Syariah & 9 & PT. Bank Syariah Bukopin \\
3 & PT. Bank BRISyariah & 10 & PT. BCA Syariah \\
4 & PT. Bank Jabar Banten Syariah & 11 & PT. Maybank Syariah Indonesia \\
5 & PT. Bank BNI Syariah & 12 & PT. BTPN Syariah \\
6 & PT. Bank Syariah Mandiri & 13 & PT. Bank Aceh Syariah \\
7 & PT. Bank Mega Syariah & 14 & PT BPD Nusa Tenggara Barat \\
\hline
\end{tabular}

Source: Islamic Banking Statistics (SPS) Period December 2018

\section{RESULTS AND DISCUSSION}

Mudharabah and musyarakah are schemes that can best distinguish between Islamic and conventional financial institutions. Both are risk-sharing based contracts that provide a fair proportion of returns. The principle of justice is one of the main principles in Islamic economics as explained by Abdul Mannan that the foundation of Islamic economics based on three fundamental concepts, namely faith in Allah (tauhid), leadership (khilafah), and justice (a'dalah) (Mannan, 1993).

The Islamic economic system supports the sharing of risk as to the preferred organizational structure for all economic activities, and supports the implementation of the most comprehensive risk-sharing and surpasses anything stated by modern economic theory (Askari, Iqbal, \& Mirakhor, 2015). 
Veithzal Rivai and Rifki Ismail explained that in Islamic economics, the risk associated with the concept of justice, where each outcome of business profits must result from involvement in dealing with business risks. Business results that are not related to the involvement in dealing with business risks are deemed not to reflect justice (Rivai \& Veithzal, 2008). However, the derivative application of Islamic economics does not yet have a comprehensive risk conception. The concept of risk in Islam is only related to the prohibition of 'gharar' and 'maisir.' The prohibition shows that Islamic economics is familiar with the asymmetric information phenomenon because the prohibition of gharar and maisir is indeed associated with the existence of the phenomenon of 'information asymmetry.'

In the context of the Islamic finance industry in Indonesia, there are several business risks that sharia banking must consider in developing its products. Bank Indonesia Regulation Number 13/23/PBI/2011 concerning Application of Risk Management for Sharia Commercial Banks and Sharia Business Units article 5 explains that there are 10 risks that must be managed by Islamic banks in carrying out their functions namely credit/financing risk, market risk, liquidity risk, operational risk, legal risk, reputation risk, strategic risk, compliance risk, return risk, and investment risk.

Table 3. Risk Types of Islamic Banking

\begin{tabular}{|c|c|}
\hline Risk Types & Description \\
\hline Credit Risk & $\begin{array}{l}\text { Credit risk is a risk due to the failure of a customer or other party to fulfill } \\
\text { a bank's obligations following an agreed agreement. }\end{array}$ \\
\hline Market Risk & $\begin{array}{l}\text { Market risk is the risk in the balance sheet and administrative account } \\
\text { position due to changes in market prices, including the risk of changes in } \\
\text { the value of assets that can be traded or leased. }\end{array}$ \\
\hline Liquidity Risk & $\begin{array}{l}\text { Risk is due to the inability of banks to fulfill maturing obligations from } \\
\text { cash flow funding sources and high-quality liquid assets that can pledge, } \\
\text { without disrupting the activities and financial condition of the bank. }\end{array}$ \\
\hline Operational Risk & $\begin{array}{l}\text { Risk of loss caused by inadequate internal processes, internal process } \\
\text { failures, human errors, system failure, and external events that affect the } \\
\text { bank's operations. }\end{array}$ \\
\hline Legal Risk & $\begin{array}{l}\text { Risk due to lawsuits and weaknesses in juridical aspects. This risk arises, } \\
\text { among others, due to the absence of supporting legislation or weaknesses } \\
\text { in the engagement, such as the failure to fulfill the validity of contracts } \\
\text { or the binding of collateral that is not perfect. }\end{array}$ \\
\hline Reputation Risk & $\begin{array}{l}\text { Reputation risk is a risk due to a decline in the level of stakeholder trust } \\
\text { that comes from negative perceptions of the bank. }\end{array}$ \\
\hline Strategic Risk & $\begin{array}{l}\text { Strategic risk is a risk due to inaccuracy in making and implementing a } \\
\text { strategic decision and failure to anticipate changes in the business } \\
\text { environment. }\end{array}$ \\
\hline Compliance Risk & $\begin{array}{l}\text { Compliance risk is a risk due to banks not complying with and / or not } \\
\text { implementing applicable laws and regulations and Sharia Principles. }\end{array}$ \\
\hline Risk of Returns & $\begin{array}{l}\text { The rate of return risk is the risk due to changes in the rate of return paid } \\
\text { by the bank to the customer due to changes in the rate of return received } \\
\text { by the bank from the distribution of funds, which can affect the behavior } \\
\text { of customers of the bank's third-party funds. }\end{array}$ \\
\hline
\end{tabular}




\begin{tabular}{cl}
\hline \multicolumn{1}{c}{ Risk Types } & \multicolumn{1}{c}{ Description } \\
\hline Investment Risk & $\begin{array}{l}\text { Investment risk is a risk due to banks taking the loss of the customer's } \\
\text { business financed in profit-sharing-based profit sharing. }\end{array}$ \\
\hline
\end{tabular}

Source: PBI No.13 / 23 / PBI / 2011 dated November 2, 2011, concerning Application of Risk Management for Sharia Commercial Banks and Sharia Business Units.

Based on tab three above, the first eight risks are general risks that are also faced by conventional banks. The last two risks are risks faced explicitly by Islamic banks. The addition of these two risks is in line with the risk management platform issued by the Islamic Financial Service Board (IFSB). The IFSB establishes fifteen risk management principles that can apply to commercial banks, investment banks, and other financial institutions. The fifteen principles covered in six risks, namely credit risk, investment risk, liquidity risk, operational risk, yield risk, and market risk. In addition to these six risks, two risks are also crucial for Islamic banks to manage, namely business risk and reputation risk (Wahyudi \& Dkk., 2013).

Adiwarman A. Karim explained that there are several types of risks related to business, including businesses carried out by Islamic banks, including the following: (1) Market risk is a risk related to the value of equity that is not ascertained, but depends on the ups and downs of the investment value in the market; (2) Corporate risk is the risk of securities market value that will change due to the company's fundamental factors; (3) Liquidity risk is the risk associated with the ability to meet cash needs (cash flow) immediately and at the appropriate cost; (4) Concentration risk is the risk of portfolio assets raised due to disclosure of another risk discussed; (5) Exchange rate risk is a risk caused by a decrease in the value of a currency in the country concerned and results in a decline in the value of the investment that dominates the exchange rate; (6) Sovereign risk is a risk caused by government intervention in the market and the tightening of exchange rates (Karim, 1999).

In line with what stated above, the Indonesian Bankers Association believes that six risks need to be considered by the bank in the following distribution of financing: (1) Political risk, based on policy/political stability (including economic, security, social, and cultural policies of a region/country). Political policies that are not conducive in a country can affect the debtor's business activities; (2) Risk of business nature. Each business/business has different types and levels of risk. Therefore banks must be able to understand the debtor's business activities so that they can mitigate risks to ensure that the financing facilities provided to debtors can run smoothly; (3) Geographic risk arises because of natural factors, the environment, and business allocation. Banks must be able to analyze the debtor's business location, such as whether the area is prone to disasters, how the conditions of security and access to business locations and others; (4) Risk of competition. Banks must pay attention to how the level of business competition of the debtor in the market share it enters and the concentration of financing in a business segment; (5) Risk of business uncertainty. Accuracy in conducting analysis and projections on the business conditions of the debtor, whether in the start-up, growth, mature or decline stages; (6) Risk of 
inflation. As a result of the value of money calculated in the cost of funds (I. B. Indonesia, 2015).

The excellent and inadequate risk management carried out by Islamic banking managers will undoubtedly have an impact on the rate of return from financing provided by Islamic banking, especially the data shows that Islamic banking financing in Indonesia is almost concentrated or at least very dominant in murabahah financing, its can be seen in Table 4 as follows:

\section{Table 4. Financing of Sharia Commercial Banks (BUS) and Sharia Business Units (UUS) Based on the Type of Contract for the period 31 December 2018 (In Millions of Rupiah)}

\begin{tabular}{clcccc}
\hline \multirow{2}{*}{ No } & \multirow{2}{*}{ Contract Type } & \multicolumn{2}{c}{ Financing Total } & \multicolumn{2}{c}{ Percentage (\%) } \\
\cline { 3 - 6 } & & BUS & UUS & BUS & UUS \\
\hline 1 & Mudharabah & 5.477 & 10.389 & 2,71 & 8,81 \\
2 & Musyarakah & 68.644 & 60.997 & 33,93 & 51,74 \\
3 & Murabahah & 118.134 & 36.671 & 58,40 & 31,10 \\
4 & Qardh & 6.848 & 826 & 3,39 & 0,70 \\
5 & Istishna' & 15 & 1.594 & 0,001 & 1,35 \\
6 & Ijarah & 3.180 & 7.417 & 0,16 & 6,29 \\
\hline
\end{tabular}

Source: Islamic Banking Statistics, Financial Services Authority (OJK) (www.ojk.go.id Accessed February 20, 2019)

Based on table 4 above, it can see that murabahah financing is the most significant financing of the total BUS financing in the 2018 period, reaching $58.40 \%$ while the most substantial UUS financing in the musyarakah financing contract is $51.74 \%$ of the total funding provided by UUS. According to Dawam Raharjo (2015), this is due to the form of murabahah transactions, which are more straightforward in terms of procedures and risks. Also, murabaha is the most preferred by customers because it is relatively easy to access even though the profit-sharing costs are lower than current bank interest.

In the context of the Indonesian economy today, from the many risks that can be experienced by Islamic banks, financing risk, market risk, return risk and investment risk are four risks that are predicted to have a significant influence on profitability fluctuations and slow growth in the market share of Islamic banking.

According to Bank Indonesia Regulation Number, 13/23 / PBI / 2011, credit risk or financing risk is a risk due to the failure of customers or other parties to fulfill obligations to the Bank following the agreed agreement. Irham Fahmi argues that credit risk or financing risk is a form of the inability of a company, agency, institution, or person to settle their obligations promptly both at maturity and after maturity (Fahmi, 2007), while Adiwarman A. Karim explained that financing risk is a risk caused by a counterparty failure in fulfilling its obligations. In Islamic banks, financing risk covers product-related risks and risks associated with corporate financing (Karim, 2014). 
The slowdown in the national economy has reduced the real income of the people as sharia bank customers so that the ability of customers to repay financing to Islamic banks has also decreased. Islamic Banks certainly has the potential to cause the failure of the customer to make a refund at the time of maturity or in risk management terminology known as credit/financing risk. Thus, it is clear that the rise of Non-Performing Financing (NPF) of BUS and UUS in Indonesia today, as shown in table 1.1, makes the risk of credit/Islamic bank financing high. The high risk of Islamic bank financing characterized by high NPF is caused by several things, as shown in table 5, as follows (Rustam, 2013).

\section{Table 5. Causes of Problematic Financing from Credit Risk Aspects}

\begin{tabular}{ll}
\hline \multicolumn{1}{c}{ Qualitative aspects } & \multicolumn{1}{c}{ Quantitative Aspects } \\
\hline $\begin{array}{l}\text { Business and industrial cycles decline; for } \\
\text { example, palm oil prices decline, etc. }\end{array}$ & Cash flow is too over-optimistic \\
$\begin{array}{l}\text { The high dependence of raw materials on } \\
\text { suppliers }\end{array}$ & Side streaming financing usage \\
$\begin{array}{l}\text { Debtor intervention in KAP in preparing } \\
\text { financial statements }\end{array}$ & $\begin{array}{l}\text { The selling price of debtor products is not } \\
\text { competitive }\end{array}$ \\
$\begin{array}{l}\text { Shareholder reputation is not good } \\
\text { Shareholders do not commit the going concern } \\
\text { of the company's business }\end{array}$ & $\begin{array}{l}\text { Mark up the price of the project } \\
\text { Debtors do not have expertise in their fields }\end{array}$ \\
& $\begin{array}{l}\text { Low sales realization compared to debt targets } \\
\text { between companies in the group are not } \\
\text { adequately presented }\end{array}$ \\
\hline
\end{tabular}

Source: PBI No.13/23/PBI/2011 dated November 2, 2011, concerning Application of Risk Management for Sharia Commercial Banks and Sharia Business Units

In order to mitigate financing risks, Islamic banks in Indonesia must discipline in applying the IFSB principles to credit risk. The principles appear in table 6 as follows:

\section{Table 6. Islamic Financial Services Board Principles for Credit Risk}

\begin{tabular}{ll}
\hline Principle 2.1 & $\begin{array}{l}\text { Islamic banks must have a financing strategy by using various instruments that } \\
\text { are following sharia and recognize potential credit exposures that may occur at } \\
\text { different stages of various financing agreements. }\end{array}$ \\
Principle 2.2 & $\begin{array}{l}\text { Islamic banks must conduct due diligence before deciding on the right choice of } \\
\text { the appropriate financing instrument. }\end{array}$ \\
Principle 2.3 & $\begin{array}{l}\text { Islamic banks must have a methodology for measuring and reporting } \\
\text { appropriate credit risk exposures for each Islamic financing instrument. }\end{array}$ \\
Principle 2.4 & $\begin{array}{l}\text { Islamic banks must have appropriate credit risk mitigation techniques for } \\
\text { Islamic financing instruments. }\end{array}$ \\
\hline
\end{tabular}

Source: PBI No.13/23/PBI/2011 dated November 2, 2011, concerning Application of Risk Management for Sharia Commercial Banks and Sharia Business Units 
In addition to having to be disciplined with the principles of the IFSB, Islamic banks in Indonesia must also be able to map the financing risks for each financing product. Adiwarman A. Karim provides a mapping of the financing risks inherent in each financing scheme, as shown in Table 7 as follows:

Table 7. Islamic Bank Financing and Risk

\begin{tabular}{ll}
\hline \multicolumn{1}{c}{ Financing } & \multicolumn{1}{c}{ Risk } \\
\hline Murabahah & Financing in the long term poses a risk of not competing for \\
profit sharing to third party funds & If the leased item belongs to the bank, the risk is the \\
unproductive assets of ijarah due to the absence of customers. & If the bank does not own the goods that leased, the risk is \\
& damage to the goods by the customer beyond regular use; \\
& therefore, a covenant for compensation for damage to goods \\
& that are not caused by regular use requires. \\
& If given in the form of services, the risk is not the service \\
& provider's performance. Therefore, the required risk covenant \\
& is the responsibility of the customer because the customer \\
& himself chooses the service provider. \\
& If the payment is with a balloon payment, the payment of a \\
large installment at the end of the risk period is a risk of the \\
customer's inability to pay it. This risk can overcome \\
extending the lease period. \\
Risk of failing to deliver goods Risk of falling goods prices
\end{tabular}

Source: PBI No.13/23/PBI/2011 dated November 2, 2011, concerning Application of Risk Management for Sharia Commercial Banks and Sharia Business Units

The other risk that has a significant influence on profitability fluctuations and the slowing growth of the market share of Islamic banks in Indonesia is market risk. According to Bank Indonesia Regulation Number 13/23 / PBI / 2011 that market risk is the risk on balance sheet and administrative account positions due to changes in market prices, among others, the risk of changes in the value of assets that can trade or leased (B. Indonesia, 2011). Bambang Rianto Rustam explained that risks in balance sheet and administrative account positions due to changes in market prices, including risk in the form of changes in the value of assets that can be traded or leased, market risks include, among others, exchange rate risk, commodity risk, and equity risk (Rustam, 2013).

The Indonesian Bankers Association explains that market risk is the risk of price changes in balance sheet positions and administrative accounts, including derivatives, due to overall changes in market conditions, including the risk of changes in option prices (I. B. Indonesia, 2015). In other words, market risk is the risk of loss for positions inside or outside the balance sheet that arise because of changes in market prices, in this case, the risk arises because it caused by changes in interest rates, exchange rates, stock prices and commodity prices (Fahmi, 2007). 
In the context of Indonesia's macroeconomy, market risk can see from the movement of the rupiah exchange rate against foreign currencies, especially the United States Dollar which during the 2018 period fluctuated as illustrated in table 8 as follows:

Table 8. Comparison of the Rupiah Exchange Rate Against the US Dollar Period January 2, 2018, and December 31, 2018

\begin{tabular}{lcc}
\hline \multicolumn{1}{c}{ Date } & Selling Rate & Buying rate \\
\hline January 2, 2018 & 13,610 & 13,474 \\
December 31, 2018 & 14,553 & 14,409 \\
\hline
\end{tabular}

Source: Bank Indonesia (www.bi.go.id. Accessed February 20, 2019)

Based on table 8 above, it can seem that in 2018, the exchange rate depreciated, the exchange rate per January 2, 2018, is Rp. 13,610 for the selling rate and $\mathrm{Rp}$. 13,474 for the buying rate, the figure has depreciated so that as of December 31, 2018, it is at the level of Rp. 14,553 for the selling rate and Rp. 14,409 for the buying rate. The depreciating rupiah exchange rate provides an opportunity for undesirable results for business actors who are investment partners of Islamic banks in Indonesia, thus creating a risk of disruption of liquidity and profitability of Islamic banks.

According to the Indonesian Bankers Association, for foreign exchange banks, the foreign exchange business is one that has the potential to provide profits for the bank, while simultaneously serving the interests of customers in foreign exchange needs. For foreign exchange-related activities, banks generally maintain positions, both long positions (foreign currency assets greater than foreign currency liabilities) and short positions (foreign exchange liabilities are more significant than foreign currency assets) (I. B. Indonesia, 2016a). Long or short positions will cause an exchange rate gap and potentially cause a loss if the exchange rate changes. The Bank determines the exchange rate gap for each primary foreign exchange type and determines the impact of changes in exchange rates on bank profit and loss. If the bank does not have an idea of the conditions of changes in exchange rates, then the best way is to seek the number of foreign exchange assets more or less the same as the same foreign exchange liabilities to avoid losses due to changes in exchange rates.

Besides being seen from the exchange rate movements, market risk also can see from the fluctuations in commodity prices in general, which can be measured by the inflation rate, as illustrated in table 9 as follows. 
Jurnal Ilmiah Al-Syir'ah Vol. 17, No. 2 (2019): 131-149

Website: http://journal.iain-manado.ac.id/index.php/JIS

ISSN 2528-0368 (online) ISSN 1693-4202 (print)

142

Table 9. Inflation Development for January 2018 period December 2018

\begin{tabular}{clc}
\hline No & \multicolumn{1}{c}{ Period } & Inflation \\
\hline 1 & \multicolumn{1}{c}{2} & 3 \\
\hline 1 & January & $3.25 \%$ \\
2 & February & $3.18 \%$ \\
3 & March & $3.40 \%$ \\
4 & April & $3.41 \%$ \\
5 & May & $3.23 \%$ \\
6 & June & $3.12 \%$ \\
7 & July & $3.18 \%$ \\
8 & August & $3.20 \%$ \\
9 & September & $2.88 \%$ \\
10 & October & $3.16 \%$ \\
11 & November & $3.23 \%$ \\
12 & December & $3.13 \%$ \\
\hline
\end{tabular}

Source: www.bi.go.id (www.bi.go.id. Accessed February 20, 2019)

Based on table 9 above, it can see that the inflation rate as an illustration of commodity price movements in general in Indonesia in 2018 has fluctuated. Inflation certainly has a significant social and economic impact on the business climate in Indonesia, including investment planning and operational efficiency of Islamic banking in Indonesia. According to Ekawarna and Fachruddiansyah, that inflation can cause social costs in the form of lowering the level of people's welfare, reducing income distribution, and disrupting economic stability (Ekawarna \& Fachruddiansyah, 2010).

Graph 1. Development of Inflation Rate for January 2018 and December 2019

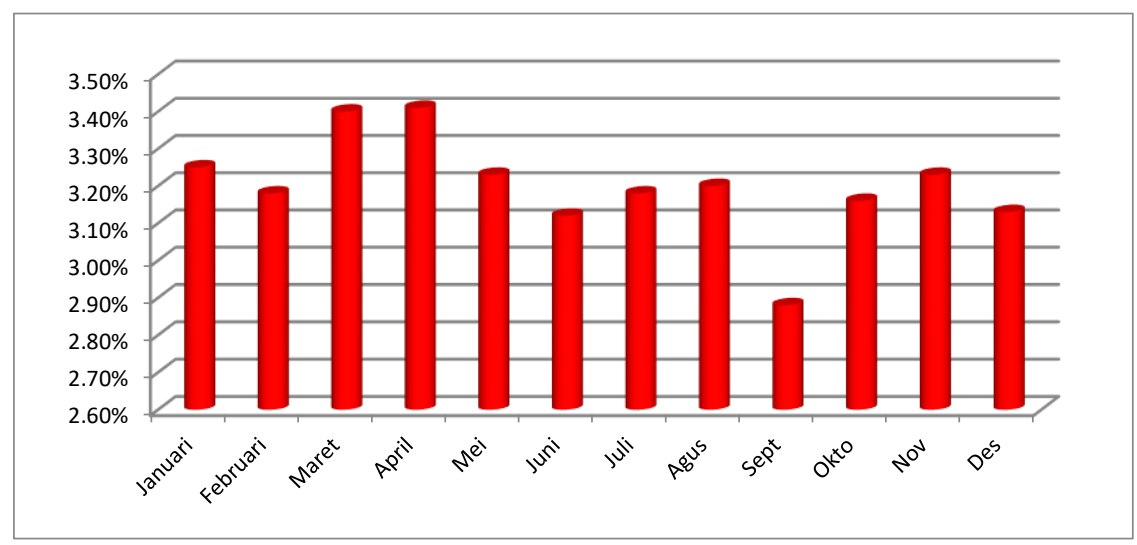

Source: www.bi.go.id (www.bi.go.id. Accessed February 20, 2019)

Graph 1 above confirms that inflation occurring in Indonesia during the 2018 period has fluctuated and indicates the existence of market risk for business actors. Mankiw N. Gregory explained that inflation raises social costs for society, including menu costs, the cost of variability in relative prices, microeconomic inefficiencies in resource allocation, tax distortion, 
and inconvenience in making inflation corrections. Also, unexpected inflation causes arbitrary wealth redistribution between debtors and creditors (Mankiw, 2013).

According to Herlan Firmansyah and Wiji Purwanta that inflation that occurs in an economy has several impacts, including the value of a currency, which will decline, and the purchasing power of the currency will be lower (Firmansyah \& W, 2014). A further decline in the purchasing power of the currency will have an impact on individuals and the business world. In other words, a high inflation rate can adversely affect the economy as a whole, and inflation causes an unstable environment for economic conditions. Inflation also tends to lower the real interest rate and cause imbalances in the capital market, this causes the supply of funds for investment to decline, and as a result, private sector investment decreases to below its equilibrium level. The impact of inflation contributes to market risk for the activities of the financial services industry.

In order to mitigate market risk, Islamic banks in Indonesia must discipline in applying the IFSB principle to market risk. The principle is shown in table 1.10 as follows:

Table 10. Islamic Financial Services Board Principles for Market Risk

Principle 4 Islamic banks must have an appropriate framework regarding market risk management (including reporting) in favor of all assets owned, including assets that are not ready to be sold or face high price volatility.

Source: PBI No.13/23/PBI/2011 dated November 2, 2011, concerning Application of Risk Management for Sharia Commercial Banks and Sharia Business Units

Based on the IFSB principle for the above-market risk, Islamic banks must form a healthy and comprehensive market risk management and information system process which contains, among others, the following: (1) A conceptual framework to encourage identification of underlying market risks; (2) Guidelines for managing risk-taking activities in different portfolios on limited investment and market risk limits; (3) He right pricing framework, valuation, and revenue recognition; (4) A stable Management Information System (SIM) for controlling, monitoring, and reporting market risk exposures and senior management performance (Rustam, 2013).

The third risk that has a significant effect on profitability fluctuations and the slowing growth of the market share of Islamic banks in Indonesia is the risk of yield. According to Bank Indonesia Regulation Number 13/23 / PBI / 2011 that risk returns are a risk due to changes in the level of returns paid by banks to customers because there is a change in the rate of return received by banks from channeling funds, which can affect the behavior of third party funds bank. 
According to Imam Wahyudi, the yield risk is due to changes in the rate of return received by the bank from the distribution of funds to the debtor. When placing funds in a bank, customers have expected returns to be obtained (Wahyudi \& Dkk., 2013). For rational customers, changes in yield expectations will affect their behavior Changes in these expectations can be caused by internal factors, such as decreasing the value of bank assets, decreasing bank revenue sharing from debtors, and defaulting on debtors, and external factors, such as rising yields offered another bank. Changes in the expected rate of return can trigger the transfer of funds to other banks.

There are three indicators that can use as measurement of risk-return profile, namely; first, the composition of third party funds by looking at the proportion of Non-Core Deposit (NCD), namely demand deposits, savings, and deposits that are not guaranteed by the Deposit Insurance Corporation (nominal higher than Rp. 2 billion) on TPF; second, the bank's strategy and performance in generating profit / income, namely by looking at NPF and ROA; third, the behavior of customers of third party funds (I. B. Indonesia, 2016b).

Among the indicators that show the risk profile of returns from Islamic banking in Indonesia are Non-Core Deposits (NCD) to the total Third Party Funds (DPK) in BUS and UUS as shown in table 11 as follows:

Table 11. Development of Non-Core Deposit (NCD) for Third Party Funds (DPK) Sharia Commercial Bank (BUS) and Sharia Business Unit (UUS) 2014-2018 Period (in Percentage/\%)

\begin{tabular}{cccc}
\hline No & Period & Sharia Commercial Bank (BUS) & Sharia Business Unit (UUS) \\
\hline 1 & 2014 & 52,91 & 56,65 \\
2 & 2015 & 50,35 & 56,94 \\
3 & 2016 & 58,84 & 60,89 \\
4 & 2017 & 51,29 & 65,92 \\
5 & 2018 & 47,69 & 66,93 \\
\hline
\end{tabular}

Source: Islamic Banking Statistics, Financial Services Authority (OJK) (www.ojk.go.id Accessed February 20, 2019)

Based on table 11 above, it can see that the NCDs of BUS and UUS during the 2014-2018 period fluctuated. Especially for 2017 and 2018, the trend has decreased from the 2016 period. NCD is part of deposits that are not permanent or unstable in the bank, meaning that they can withdraw at any time (Harun \& Nattan, 2013). According to the Indonesian Bankers Association, NCDs are demand deposits, savings, and deposits that are not guaranteed by the Deposit Insurance Corporation (LPS) with a nominal value higher than Rp. 2 billion (I. B. Indonesia, 2016). When the yield provided by a small Islamic bank, the NCD will be low because customers tend to withdraw their deposits to transfer to other financial portfolios. Conversely, if the returns from Islamic banks are high, then the level of trust and 
confidence of customers towards Islamic banks will be high in NCD funds will also be high.

In order to mitigate returns on risk, Islamic banks in Indonesia must discipline in applying the principles of IFSB to risk returns. The principles are shown in table 12 as follows:

\section{Table 12. Principles of the Islamic Financial Services Board for Risk of Returns}

\begin{tabular}{ll}
\hline Principle 6.1 & $\begin{array}{l}\text { Islamic banks must have a comprehensive risk management and reporting } \\
\text { process to assess the potential impact of market factors that affect asset returns } \\
\text { compared to the expected rate of return on investment account holders. }\end{array}$ \\
Principle 6.2 & $\begin{array}{l}\text { Islamic banks must have a framework for managing commercial risks that are } \\
\text { misplaced where needed. }\end{array}$ \\
\hline
\end{tabular}

Source: PBI No.13/23/PBI/2011 dated November 2, 2011, concerning Application of Risk Management for Sharia Commercial Banks and Sharia Business Units

The fourth risk that has a significant influence on profitability fluctuations and the slowing growth of the market share of Islamic banks in Indonesia is the risk of investment. According to Bank Indonesia Regulation Number 13/23 / PBI / 2011 that investment risk is a risk as a result of the bank taking responsibility for the loss of the customer's business financed in profitloss sharing. Among the indicators that indicate the investment risk of Islamic banking are the potential loss of profit-sharing financing to the mudharabah and musyarakah investment portfolios in BUS and UUS, as shown in Table 13 as follows:

Tabel 13. Development of Potential Losses in Profit Sharing Financing for Mudharabah and Musyarakah Investment Portfolios Sharia Commercial Bank (BUS) and Sharia Business Unit (UUS) 2014-2018 Period (in Percentage/\%)

\begin{tabular}{cccc}
\hline No & Period & Sharia Commercial Bank (BUS) & $\begin{array}{c}\text { Sharia Business Unit } \\
\text { (UUS) }\end{array}$ \\
\hline 1 & 2014 & 2,56 & 1,84 \\
2 & 2015 & 2,81 & 2,75 \\
3 & 2016 & 3,40 & 1,97 \\
4 & 2017 & 3,29 & 1,43 \\
5 & 2018 & 3,47 & 1,71 \\
\hline
\end{tabular}

Source: Islamic Banking Statistics, Financial Services Authority (OJK) (www.ojk.go.id Accessed February 20, 2019)

Based on table 13 above, it can seem that the development of potential loss of profit-sharing financing for the mudharabah investment portfolio and musharaka of BUS and UUS during the 2014-2018 period fluctuated. Especially for the 2018 period, the potential loss of profit-sharing financing to the mudharabah and musyarakah investment portfolios, both BUS and 
UUS, has increased, this shows that the investment risk from profit-based financing activities as the identity of Islamic bank financing has the potential to cause problems, especially problems with the efforts of Islamic banks to achieve the expected level of profit.

In order to mitigate investment risk, Islamic banks in Indonesia must discipline in applying the principles of IFSB for investment risk. The principles appear in table 14 as follows.

\section{Table 14. Islamic Financial Services Board Principles for Investment} Risk

\begin{tabular}{ll}
\hline Principle 3.1 & Islamic banks must have a strategy, risk management, and an adequate \\
& reporting process about the characteristics of investment risk, including \\
& mudharabah and musyarakah investments. \\
Principle 3.2 & Islamic banks must ensure a proper and consistent valuation methodology and \\
& must assess the potential impact of the calculation method and profit \\
& allocation. This method must mutually agree between Islamic banks and \\
& mudharib or musyarakah partners. \\
Principle 3.3 & Islamic banks must define and establish exit strategies in their capital \\
& investment activities including conditions for extension and return on \\
& mudharabah and musyarakah investments based on the approval of the \\
& Islamic bank DPS
\end{tabular}

Source: PBI No.13/23/PBI/2011 dated November 2, 2011, concerning Application of Risk Management for Sharia Commercial Banks and Sharia Business Units

Islamic banking that sharia implements principles in its operational activities should always maintain its business governance in order to remain professional, trustworthy, and provide maximum benefits. However, the reality is that the macroeconomic slowdown, exchange rate fluctuations, inflation fluctuations and declining real income of the people that have an impact on the failure of financing customers or other parties to fulfill obligations to Islamic banks by agreed agreements, have an impact on the profitability of Islamic banking.

Based on the description above and related to the field phenomena that occur in national Islamic banking, the general framework of the study can be described in chart one as follows: 
Figure 2. Risk Financing Business Risk Assessment Framework in Indonesia

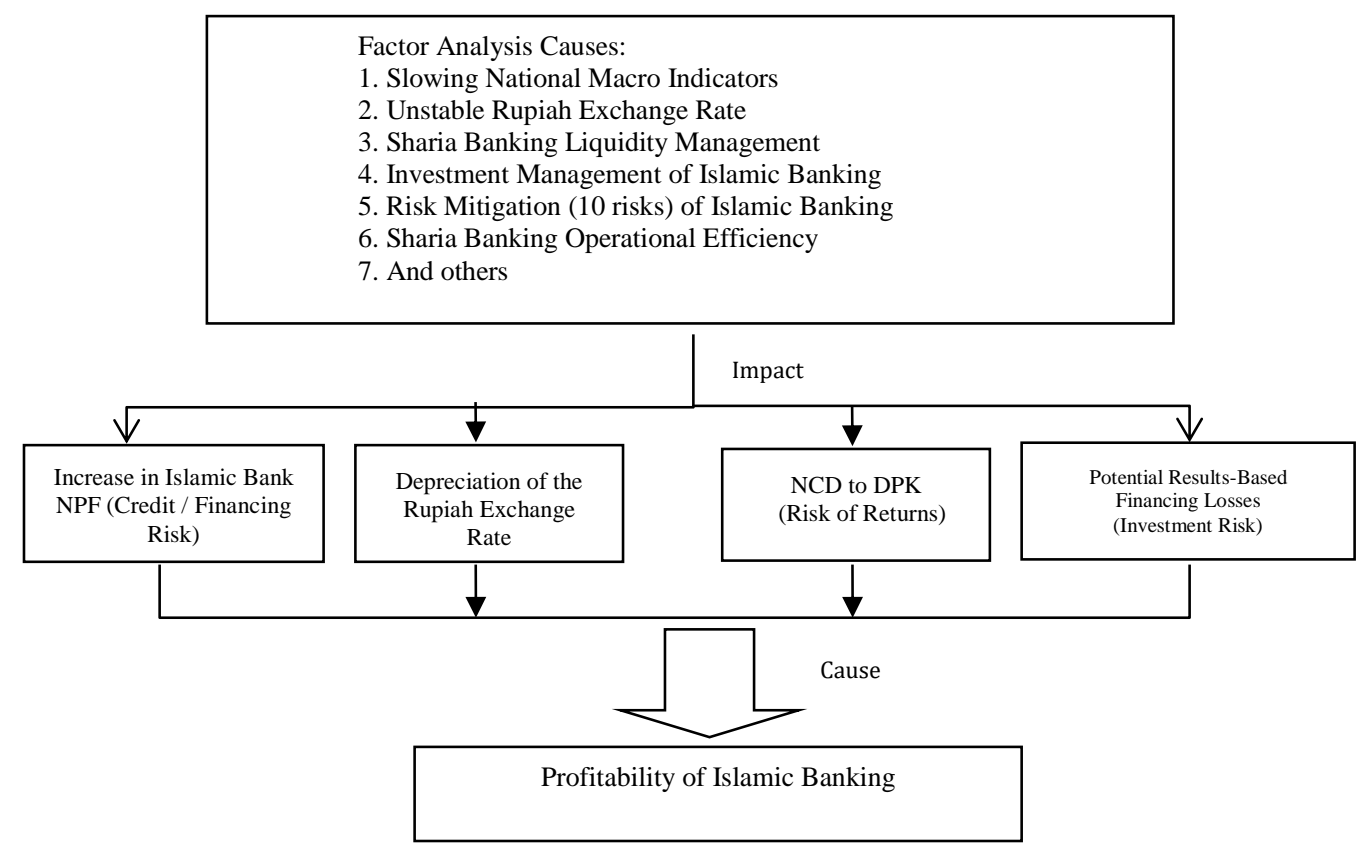

Source: PBI No.13/23/PBI/2011 dated November 2, 2011, concerning Application of Risk Management for Sharia Commercial Banks and Sharia Business Units

Based on chart 1 above, it knows that the financing risk is reflecting in the NPF value, market risk which is reflecting in the rupiah exchange rate and inflation, yield risk which is reflecting in the NCD against total deposits and investment risk reflected by potential losses from results (musyarakah and mudharabah) have an influence on fluctuations in profitability and the low market share of Islamic banking. The profitability of Islamic banking can see by looking at the returns on assets (Return on Assets / ROA) and the return on equity (Return on Equity / ROE) of Islamic banks for a specified period.

Islamic banking will always face with various types of risks with varying complexity and inherent in their business activities. Therefore, Islamic banking in Indonesia must implement risk management properly so that the expected profit level can achieve. Efficient risk management is how Islamic banks can reduce all business risks. The absence of a sound and robust risk management system can eliminate Islamic banks from their ability to overcome risks and can reduce their potential contributions (Yulianti, 2009).

The objectives of sharia bank risk in policies are to identify, measure, monitor, and control the course of business activities of banks with a reasonable level of risk that is directing, integrated, and sustainable. Thus, risk management functions as a filter or early warning system for business activities carried out by Islamic banks (Fasa, 2016). 


\section{CONCLUSION}

Four financing business risks trigger the fluctuations in profitability and the slowing growth of the market share of Islamic banks in Indonesia, namely financing risk, market risk, yield risk, and investment risk. In the context of Indonesia's macroeconomy, empirical data about the four factors during the study period (2014-2018 period) fluctuated so that it affected the operations of Islamic banking businesses in Indonesia and ultimately affected the ability of Islamic banking to generate profits (profitability). Financing risk is a risk due to the failure of customers or other parties to fulfill obligations to the Bank following the agreed agreement. While market risk that the risk in the balance sheet and administrative account position to changes in market prices, including the risk of changes in the value of assets that can be traded or lease. The risk of return is a risk due to changes in the level of returns paid by the bank to customers because there is a change in the rate of return received by the bank from the distribution of funds, which can affect the behavior of customers of the bank third party funds while investment risk is a risk as a result of the bank taking part in the loss of the customer's business financed in profit-loss sharing. Funding risk is reflecting in the NPF value, market risk including reflected in the rupiah exchange rate and inflation, the risk of which is reflected in the value of NCD to total deposits and investment risk reflected in the percentage of potential profit sharing for the mudharabah and musyarakah investment portfolios, while profitability one of which is reflected in the Return on Asset (ROA) ratio.

\section{ACKNOWLEDGMENTS}

The author thanks the Chancellor and Vice Chancellors of Suryakancana University, Deans, Vice Deans and colleagues of the Faculty of Islamic Economics and Business of the Universitas Suryakancana and the Faculty of Sharia and Law at the State Islamic University Sunan Gunung Djati Bandung for supporting the completion of this article.

\section{REFERENCES}

Ansori, H. R., \& Safira, S. (n.d.). Analisis Pengaruh Manajemen Risiko Terhadap Profitabilitas. Jurnal Profita, 11(1), 1-19.

Arif, M. N. R. Al. (2012). Lembaga Keuangan Syariah. Bandung: Pustaka Setia.

Askari, H., Iqbal, Z., \& Mirakhor, A. (2015). Introduction to Islamic Economics: Theory and Application. Singapore: John Wiley \& Sons.

Dantes, N. (2012). Metode Penelitian. Yogyakarta: CV ANDI OFFSET.

Ekawarna, E., \& Fachruddiansyah, F. (2010). Ekawarna dan Fachruddiansyah, Pengantar Teori Ekonomi Makro. Jakarta: Gaung Persada.

Fahmi, B. (2007). Manajemen Risiko. Jakarta: Grasindo.

Fasa, M. I. (2016). Manajemen Resiko Perbankan Syariah di Indonesia. Li Falah. Jurnal Studi Ekonomi Dan Bisnis Islam, 1(2).

Firmansyah, H., \& W, P. (2014). Ekonomi Muatan Kebanksentralan. Jakarta: Bank Indonesia dan Kementerian Pendidikan dan Kebudayaan. 
Harun, C. A., \& Nattan, R. (2013). Non Core Deposit: Studi terhadap Dana Pihak Ketiga Perbankan di Indonesia. Jakarta: Bank Indonesia.

Hery, H. (2015). Analisis Laporan Keuangan Pendekatan Rasio Keuangan. Jakarta: Buku Seru.

Indonesia, B. (2011). Peraturan Bank Indonesia (PBI) Nomor 13/23/PBI/2011 tentang Penerapan Manajemen Risiko bagi Bank Umum Syariah dan Unit Usaha Syariah. Bank Indonesia.

Indonesia, I. B. (2015a). Manajemen Risiko 1: Mengidentifikasi Risiko Pasar, Operasional dan Kredit Bank. Jakarta: Gramedia Pustaka Utama.

Indonesia, I. B. (2015b). Mengelola Bisnis Pembiayaan Bank Syariah. Jakarta: Gramedia Pustaka Utama.

Indonesia, I. B. (2016a). Manajemen Kesehatan Bank berbasis Risiko. Jakarta: Gramedia Pustaka Utama.

Indonesia, I. B. (2016b). Supervisi Manajemen Risiko Bank. Jakarta: Gramedia Pustaka Utama.

Karim, A. A. (1999). Adiwarman A. Karim, Modul Certificate Islamic Finance Analisys, Islamic Finance and Islamic Capita Market. Jakarta: EKONISIA FE UI.

Karim, A. A. (2014). Bank Islam: Analisis Fiqih dan Keuangan. Jakarta: PT. Raja Grafindo Persada.

Mankiw, N. G. (2013). Macroeconomics (8 ed.). New York USA: Charles Linsmeier.

Mannan, A. M. (1993). Understanding Islamic Finance: A. Study of Securities Market in the Islamic Framework. Islamic Research and Training Institute of IDB.

Muhammad, M. (2000). Lembaga-lembaga Keuangan Umat Kontemporer. Yogyakarta: Multi Karya Grafika.

Rivai, V., \& Veithzal, A. P. (2008). Islamic Financial Management: Teori, Konsep, dan Aplikasi Panduan Praktis untuk Lembaga Keuangan, Nasabah, Praktisi, dan Mahasiswa. Jakarta: Rajawali Press.

Rustam, B. R. (2013). Manajemen Risiko Perbankan Syariah di Indonesia. Jakarta: Salemba Setia.

Saebani, B. A., \& Abdullah, B. (2014). Metode Penelitian Ekonomi Islam. Bandung: Pustaka Setia.

Sidiq, R. (2018). Analisis Pengaruh Jenis Produk Pembiayaan Dan Risiko Bank Terhadap Profitabilitas Perbankan Syariah Di Indonesia. Universitas Islam Indonesia Yogyakarta.

Suryani, S., \& Hendryadi, H. (2015). Metode Riset Kuantitatif: Teori dan Aplikasi pada Penelitian Bidang Manajemen dan Ekonomi Islam. Jakarta: Prenada Group.

Wahyudi, I., \& Dkk. (2013). Manajemen Risiko Bank Islam. Jakarta: Salemba Setia.

Yulianti, R. T. (2009). La Riba. Jurnal Ekonomi Islam, 3(2). 